\title{
The Antioxidant Defense System during Lanzhou Lily Scales Storage Is Modulated by Hydrogen Sulfide
}

\author{
Changxia Li ${ }^{1}$, Guibao Chen ${ }^{2}$, Dengjing Huang ${ }^{1}$, Ni Wang ${ }^{1}$ and Weibiao Liao ${ }^{1, *(D)}$ \\ 1 College of Horticulture, Gansu Agricultural University, 1 Yinmen Village, Anning District, \\ Lanzhou 730070, China; licx_gsau@163.com (C.L.); 3032@163.com (D.H.); wangni19941011@163.com (N.W.) \\ 2 Lanzhou New District Urban Development Investment Group Co., Ltd., Lanzhou Xin District, \\ Lanzhou 730070, China; chengb_014630@163.com \\ * Correspondence: liaowb@gsau.edu.cn; Tel.: +86-931-7631145
}

Citation: Li, C.; Chen, G.; Huang, D.; Wang, N.; Liao, W. The Antioxidant Defense System during Lanzhou Lily Scales Storage Is Modulated by Hydrogen Sulfide. Horticulturae 2021, 7, 183. https://doi.org/10.3390/ horticulturae7070183

Academic Editors: Tianbao Yang and Jorge M. Fonseca

Received: 13 June 2021

Accepted: 2 July 2021

Published: 5 July 2021

Publisher's Note: MDPI stays neutral with regard to jurisdictional claims in published maps and institutional affiliations.

Copyright: (c) 2021 by the authors. Licensee MDPI, Basel, Switzerland. This article is an open access article distributed under the terms and conditions of the Creative Commons Attribution (CC BY) license (https:// creativecommons.org/licenses/by/ $4.0 /)$.

\begin{abstract}
As an important gaseous regulator, hydrogen sulfide $\left(\mathrm{H}_{2} \mathrm{~S}\right)$ is involved in various aspects of plant processes, including seed germination, stomatal movement, and postharvest senescence. The preservation capacity of Lanzhou lily (Lilium davidii var. unicolor Salisb) scales fumigated with or without exogenously applied sodium hydrosulfide (NaHS, a $\mathrm{H}_{2} \mathrm{~S}$ donor) was investigated in the current study. Results indicate that NaHS fumigation was able to extend storage life and elicit endogenous $\mathrm{H}_{2} \mathrm{~S}$ production of postharvest Lanzhou lily scales with an optimal concentration at $0.8 \mathrm{mM}$. Moreover, exogenously applied NaHS $(0.8 \mathrm{mM})$ led to higher soluble sugar, soluble protein, and ascorbic acid levels and lower total phenolic and flavonoid contents compared with those of the control. The application of $0.8 \mathrm{mM}$ NaHS also reduced the lipid peroxidation level and reactive oxygen species (ROS) accumulation in scales, as indicated by the lower malondialdehyde (MDA) content, relative conductivity, lipoxygenase (LOX) activity, $\mathrm{O}_{2}{ }^{-}$production rate, and hydrogen per-oxide $\left(\mathrm{H}_{2} \mathrm{O}_{2}\right)$ content. Further, scales treated with $0.8 \mathrm{mM} \mathrm{NaHS}$ exhibited significantly higher activities of superoxide dismutase (SOD), catalase (CAT), peroxidase (POD), and ascorbic acid peroxidase (APX). Collectively, our data provide new insight into how the postharvest senescence of Lanzhou lily scales might be alleviated by $\mathrm{H}_{2} \mathrm{~S}$ by enhancing antioxidant defense systems.
\end{abstract}

Keywords: fumigation; hydrogen sulfide $\left(\mathrm{H}_{2} \mathrm{~S}\right)$; lily bulbs; lipid peroxidation; postharvest senescence; quality; reactive oxygen species (ROS); storage life

\section{Introduction}

Lanzhou lily (Lilium davidii var. unicolor Salisb), a variant of L. davidii Duchartre, belongs to the genus Lilium of the family Liliaceae and is generally known as "the only sweet lily". It is mainly planted in the central area of Gansu Province in Northwest China [1]. It is also a popular edible vegetable because of its white color, thick flesh, sweetness, and distinct taste. Due to its powerful antibacterial and anti-inflammatory properties, Lanzhou lily is renowned as a traditional medicinal plant species with a 150-year-long cultivation history [2-4]. Lanzhou lily is rich in constituents such as starch, protein, fat, cellulose, saponin, colchicine, and polysaccharides [5,6]. During harvest and storage, Lanzhou lily is highly perishable and turns brown due to the thin skin of its scales. Currently, low-temperature storage combined with preservatives constitutes the universal strategy in terms of postharvest techniques of Lanzhou lily. However, low temperature triggers oxidative damage that may result in nutrient changes in Lanzhou lily [7]. Therefore, there is a need to develop suitable techniques to reduce nutrient loss and extend shelf-life.

Hydrogen sulfide $\left(\mathrm{H}_{2} \mathrm{~S}\right)$ is colorless and flammable with a characteristic odor of rotten eggs [8]. Many researchers have focused only on the environmental toxicology of $\mathrm{H}_{2} \mathrm{~S}$ in the last few decades [9]. Recently, accumulating evidence has indicated that only high sulfide concentrations have toxic effects on cells, whereas low concentrations of endogenous $\mathrm{H}_{2} \mathrm{~S}$ may have a variety of physiological functions in both plants and animals $[10,11]$. 
Consequently, $\mathrm{H}_{2} \mathrm{~S}$ is known as the third gasotransmitter, behind nitric oxide and carbon monoxide [12]. It has been reported that $\mathrm{H}_{2} \mathrm{~S}$ provided by sodium hydrosulfide (NaHS) solution is transported through the membrane by simple diffusion in plants [13]. Recently, several studies identified that, as a gaseous regulator, $\mathrm{H}_{2} \mathrm{~S}$ may play prominent roles in plant growth and development, such as seed germination [14], seedling growth [15], stomatal movement [16], and adventitious root formation [17]. Additionally, $\mathrm{H}_{2} \mathrm{~S}$ is involved in regulating plant responses to abiotic stresses, including drought stress [18,19], osmotic stress [20], salt stress [21], chilling stress [22], and heavy metal stress [23,24]. The roles of $\mathrm{H}_{2} \mathrm{~S}$ in extending the shelf-life of cut flowers were first reported by Zhang et al. [25]. The preservation behavior of $\mathrm{H}_{2} \mathrm{~S}$ has been tested on many horticultural products, including strawberry [26], broccoli [27], kiwifruit [28], pear [29], sweet potato [30], lotus root [31], water spinach [32], grape [33], and apple [34]. Nevertheless, the underlying mechanisms through which $\mathrm{H}_{2} \mathrm{~S}$ affects the postharvest preservation of horticultural products are still unclear.

Previous studies have shown that $\mathrm{H}_{2} \mathrm{~S}$ is able to maintain high nutritional quality by prolonging the shelf-life of fruits $[27,29]$. It has been reported that $\mathrm{H}_{2} \mathrm{~S}$ extends the storage time of fruits by alleviating oxidative damage $[29,34,35]$. However, there is no information about the postharvest shelf-life of plant scales due to the effects of $\mathrm{H}_{2} \mathrm{~S}$. Thus, the effects of $\mathrm{H}_{2} \mathrm{~S}$ on the storage life, endogenous $\mathrm{H}_{2} \mathrm{~S}$ level, nutritional quality, oxidative damage, and antioxidant enzymes of Lanzhou lily scales were investigated in this study. The objective of the present study was to confirm the roles of $\mathrm{H}_{2} \mathrm{~S}$ as a possible regulatory factor in the senescence of plant scales during storage.

\section{Materials and Methods}

\subsection{Plant Materials and Treatments}

Bulbs of Lanzhou lily were kindly supplied by West Orchard, Qilihe district, Lanzhou, China. Mean annual precipitation, annual average temperature, and altitude of the area are $300 \mathrm{~mm}, 7.2^{\circ} \mathrm{C}$, and $2100 \mathrm{~m}$, respectively. Bulbs were washed in running water to remove dirt, and surface was sterilized by 800 times carbendazim solution made from $50 \%$ carbendazim wettable powder for $30 \mathrm{~min}$ and then washed with distilled water three times. Lanzhou lily was harvested on 1 October 2020. The selected bulbs were of similar size, disease free, and without physical damage. The scales of layers three, four, and five have low rot rate and high quality. Thus, the outer two layers of the bulbs were peeled off and removed; scales of layers three, four, and five were obtained with similar size and without physical damage and were washed and dried for use as experimental materials. A solution of NaHS (NaHS. $3 \mathrm{H}_{2} \mathrm{O}$, Sigma) was used as a $\mathrm{H}_{2} \mathrm{~S}$ donor. Scales of Lanzhou lily were fumigated with different concentrations $(0,0.2,0.4,0.6,0.8$, and $1.0 \mathrm{mM})$ of NaHS solutions $(500 \mathrm{~mL})$ for 3 days, and the solutions were renewed daily. Each experimental unit was a $19 \mathrm{~L}$ plastic sealed container maintained at room temperature $\left(23 \pm 2{ }^{\circ} \mathrm{C}\right)$ and a relative humidity of $85-90 \%$. The scales were placed in Petri dishes, which were placed in sealed containers. The experiment was laid out in accordance with a complete randomized design. Scales (216) that were of similar size, disease free, and without physical damage were divided into six groups-five treatment groups and a control group-with three replicates, each of which included 12 scales (approximately $3.5 \mathrm{~g}$ per scale). For each treatment, 36 scales were treated. Samples were obtained every three days after treatment and were stored at $-80^{\circ} \mathrm{C}$ prior to being subjected to various experimental assays, and fresh scales were used for the evaluation of storage life and color, percentage of fresh weight (FW) change (\%), and endogenous $\mathrm{H}_{2} \mathrm{~S}$ content.

\subsection{Percentage of Fresh Weight (FW) Change (\%)}

Every other day, the FW of Lanzhou lily scales was recorded. The percentage of FW change $(\%)$ was calculated with the following formula:

$$
\text { Percentage of FW change }(\%)=\left[\left(\mathrm{W}_{\mathrm{d}}-\mathrm{W}_{\mathrm{a}}\right) /\left(\mathrm{W}_{0}-\mathrm{W}_{\mathrm{a}}\right)\right] * 100 \%
$$


where $W_{a}$ is the weight of the Petri dish; $W_{0}$ is the weight of the Petri dish and scales; $W_{d}$ is the weight of the Petri dish and scales after treatments; and $d=0,2,4,6,8,10$, and 12 days.

\subsection{Storage Life Evaluation}

The storage life of each scale was recorded as the number of days from the day that the scales were fumigated by NaHS solutions to the day that they had no market value. Browning was divided into 3 grades according to the percentage of browning area of the total scale area: grade $1(0-10 \%)$, grade $2(10-45 \%)$, and grade $3(>45 \%)$. Having a FW of $<30 \%$ in conjunction with being of grade 3 was defined as having no market value, as proposed by Al Ubeed et al. [36]. For each treatment, 12 scales were selected for evaluation, and the average was determined.

\subsection{Determination of Endogenous $\mathrm{H}_{2} \mathrm{~S}$ Content}

The content of endogenous $\mathrm{H}_{2} \mathrm{~S}$ was determined according to the method described by Zhu et al. [37], with slight modifications. Frozen scales (1.0 g) were ground in liquid nitrogen and extracted with $2 \mathrm{~mL}$ of $50 \mathrm{mM}$ phosphate-buffered saline (PBS) solution ( $\mathrm{pH}$ 6.8) consisting of $200 \mathrm{mM}$ ascorbic acid and $0.1 \mathrm{mM}$ ethylenediaminetetraacetic acid disodium salt dihydrate (EDTA-Na $)$. The extract was centrifuged at 20,000 $\mathrm{g}$ for $10 \mathrm{~min}$ at $4{ }^{\circ} \mathrm{C}$. Afterward, $1 \mathrm{~mL}$ of the supernatant was transferred to a $15 \mathrm{~mL}$ test tube that contained $2 \mathrm{~mL}$ of $100 \mathrm{mM}$ PBS solution (pH 7.4) consisting of both $10 \mathrm{mM}$ L-cysteine and $2 \mathrm{mM}$ phosphopyridoxal and $0.2 \mathrm{~mL}$ of $0.1 \%$ zinc acetate, and the contents were mixed together. After a $30 \mathrm{~min}$ reaction, $0.15 \mathrm{~mL}$ of $5 \mathrm{mM}$ dimethyl-p-phenylenediamine dissolved in $3.5 \mathrm{mM} \mathrm{H}_{2} \mathrm{SO}_{4}$ was added to the trap. Subsequently, $0.15 \mathrm{~mL}$ of $50 \mathrm{mM}$ ferric ammonium sulfate in $100 \mathrm{mM} \mathrm{H}_{2} \mathrm{SO}_{4}$ was injected into the tube and incubated for $15 \mathrm{~min}$ at $25{ }^{\circ} \mathrm{C}$. Finally, the $\mathrm{H}_{2} \mathrm{~S}$ content in the zinc acetate trap was measured at $765 \mathrm{~nm}$. A reaction solution without zinc acetate was used as a blank control.

\subsection{Detection of Soluble Sugar, Soluble Protein, Ascorbic Acid, and Total Phenolic and Flavonoid Contents}

The content of soluble sugars was analyzed according to the procedure of Yemm and Willis [38], with minor modifications. Lanzhou lily scales were dried and ground into a fine powder, and the fine powder $(0.2 \mathrm{~g})$ was placed in a test tube. The test tube was then, placed in a boiling water bath for $30 \mathrm{~min}$, rapidly cooled, and then filtered into a $50 \mathrm{~mL}$ volumetric flask. After recycling the residue into a test tube, $15 \mathrm{~mL}$ of distilled water was added, and the mixture was boiled again for $10 \mathrm{~min}$. The extracting solution was collected by using the same method. The extracting solution $(0.5 \mathrm{~mL}), 1.5 \mathrm{~mL}$ of distilled water, $0.5 \mathrm{~mL}$ of anthroneethyl acetate reagent, and $5.0 \mathrm{~mL}$ of $\mathrm{H}_{2} \mathrm{SO}_{4}(98 \%)$ were mixed together in a $25 \mathrm{~mL}$ test tube. Then, the mixture was heated in a boiling water bath for $1 \mathrm{~min}$, and the absorbance was measured at $630 \mathrm{~nm}$ at room temperature.

For determination of the soluble protein content, samples (1.0 g) were ground and extracted in $5 \mathrm{~mL}$ of distilled water. The homogenate was then centrifuged at $12,000 \times g$ at $4{ }^{\circ} \mathrm{C}$ for $20 \mathrm{~min}$. Then, $1 \mathrm{~mL}$ of the supernatant and $5 \mathrm{~mL}$ of Coomassie brilliant blue were mixed together. The absorbance at $595 \mathrm{~nm}$ was recorded after $2 \mathrm{~min}$ by the method described by Bradford et al. [39]. The results were expressed as milligrams per gram of FW.

The titrimetric method with 2,6-dicloro-phenol-indophenol reagent described by Contreras-Calderón et al. [40], with several modifications, was used. The frozen sample $(1 \mathrm{~g})$ and $5 \mathrm{~mL}$ of $2 \%$ oxalic acid solution were mixed together. The mixture was homogenized, diluted to $50 \mathrm{~mL}$ with $2 \%$ oxalic acid solution, and then filtered. Ten milliliters of the filtered solution was titrated with $0.01 \%$ 2,6-dichloro-phenol-indophenol solution. The final point occurred when the solution had a pink color for $30 \mathrm{~s}$. The ascorbic acid content was expressed as milligrams per $100 \mathrm{~g}$ of FW. The total phenol content was determined according to the methods of Liu et al. [41], with several modifications. Frozen scales (1.0 g) were ground with a mortar and pestle in $20 \mathrm{~mL}$ of $50 \%$ ethanol and incubated in a water bath at room temperature for $1 \mathrm{~h}$. Then, the mixture was filtered and diluted with distilled water to $25 \mathrm{~mL}$ for use as a crude extract. The ethanol extract of scales was added to $1.0 \mathrm{~mL}$ 
of $1 \mathrm{M}$ Folin-Ciocalteu reagent. After mixing thoroughly for $8 \mathrm{~min}, 1.5 \mathrm{~mL}$ of $7.5 \% \mathrm{Na}_{2} \mathrm{CO}_{3}$ solution was added to the mixture. The mixture was then incubated for $0.5 \mathrm{~h}$ at room temperature in the dark, and the absorbance at $765 \mathrm{~nm}$ was measured. Total phenolic content was expressed as milligrams per gram of FW.

Determination of total flavonoids in the scales was performed according to the methods of Jia et al. [42], with some modifications. One gram of scales was ground in $1 \%$ $\mathrm{HCl}$-methanol solution using a mortar and pestle. Then, the ethanol extract of scales was transferred to a $10 \mathrm{~mL}$ tube. After being incubated in darkness at $4{ }^{\circ} \mathrm{C}$ for $20 \mathrm{~min}$, the mixture was centrifuged at $3000 \mathrm{r} / \mathrm{min}$ for $20 \mathrm{~min}$. The supernatant $(1 \mathrm{~mL})$ and $0.3 \mathrm{~mL}$ of $5 \% \mathrm{NaNO}_{2}$ were mixed together. After $5 \mathrm{~min}, 0.3 \mathrm{~mL}$ of $10 \% \mathrm{Al}\left(\mathrm{NO}_{3}\right)_{3}$ was added, and after $6 \mathrm{~min}, 4 \mathrm{~mL}$ of $4 \% \mathrm{NaOH}$ was added to the mixture, which was brought to $4 \mathrm{~mL}$ with distilled water. The absorbance at $532 \mathrm{~nm}$ was read, and the content was expressed as milligrams per gram of FW.

\subsection{Determination of Malondialdehyde (MDA) Content, Relative Conductivity, $\mathrm{O}_{2}{ }^{-}$Production Rate, and Hydrogen Peroxide $\left(\mathrm{H}_{2} \mathrm{O}_{2}\right)$ Content}

The MDA content was measured by using the method described by Ma et al. [43], with slight modifications. One gram of sample tissue was homogenized in $5 \mathrm{~mL}$ of $10 \%$ trichloroacetic acid (TCA) and then centrifuged at $10,000 \times \mathrm{g}$ for $20 \mathrm{~min}$ at $4{ }^{\circ} \mathrm{C}$. The supernatant liquor ( $2 \mathrm{~mL}$ ) was added to $2 \mathrm{~mL}$ of $0.67 \%$ 2-thiobarbituric acid (TBA). The mixture was boiled in a water bath at $100{ }^{\circ} \mathrm{C}$ for $20 \mathrm{~min}$ and then centrifuged for $15 \mathrm{~min}$ at $10,000 \times g$ after cooling quickly on ice. The absorbance of the supernatant was measured at 450,532 , and $600 \mathrm{~nm}$. MDA content $\left(\mathrm{nmol} \cdot \mathrm{g}^{-1}\right)=6.45 *\left(\mathrm{OD}_{532}-\mathrm{OD}_{600}\right)-0.56 * \mathrm{OD}_{450}$.

Scales $(1 \mathrm{~g})$ circularized by a hole puncher with a diameter of $0.6 \mathrm{~mm}$ were immersed in $15 \mathrm{~mL}$ of deionized water for $1 \mathrm{~h}$, and conductivity was measured with an electrical conductivity meter (D1). The scales were then boiled for $10 \mathrm{~min}$, and the conductivity was again measured (D2). The relative conductivity was calculated according to the following equation: relative conductivity $=(\mathrm{D} 1 / \mathrm{D} 2) * 100 \%$.

The $\mathrm{O}_{2}{ }^{-}$production rate was analyzed as described by $\mathrm{Hu}$ et al. [44]. One gram of scales was homogenized with $5 \mathrm{~mL}$ of extraction buffer consisting of $1 \mathrm{mM}$ ethylenediaminetetraacetic acid (EDTA), $0.3 \%$ Triton X-100, and 2\% polyvinylpyrrolidone (PVP) and subsequently centrifuged at $12,000 \times g$ for $20 \mathrm{~min}$ at $4{ }^{\circ} \mathrm{C}$. One milliliter of $50 \mathrm{mM}$ potassium phosphate buffer, $1 \mathrm{~mL}$ of $1 \mathrm{mM}$ hydroxylamine hydrochloride, and $1 \mathrm{~mL}$ of crude extract were mixed together in a reaction tube and subsequently incubated at $25^{\circ} \mathrm{C}$ for $1 \mathrm{~h}$. Afterward, $1 \mathrm{~mL}$ of $17 \mathrm{mM}$ sulfanilic acid and $1 \mathrm{~mL}$ of $7 \mathrm{mM} \alpha$-naphthylamine were added to the reaction tube, which was incubated at $25^{\circ} \mathrm{C}$ for $20 \mathrm{~min}$, after which the absorbance was measured at $530 \mathrm{~nm}$. The content was expressed as micromoles per minute per gram of FW.

The $\mathrm{H}_{2} \mathrm{O}_{2}$ content was determined as described by Prochazkova et al. [45]. One gram of scales was homogenized in $5 \mathrm{~mL}$ of cold $100 \%$ acetone and then centrifuged at 12,000 $\times \mathrm{g}$ for $20 \mathrm{~min}$ at $4{ }^{\circ} \mathrm{C}$. The supernatant was collected immediately for $\mathrm{H}_{2} \mathrm{O}_{2}$ analysis. Sample extract $(1.0 \mathrm{~mL})$ was added to $0.1 \mathrm{~mL}$ of $10 \%$ titanium tetrachloride and $0.2 \mathrm{~mL}$ of an ammonia-water mixture. After a reaction for $5 \mathrm{~min}$, the mixtures were centrifuged at $12,000 \times g$ for $15 \mathrm{~min}$ at $4{ }^{\circ} \mathrm{C}$. The supernatant fraction was discarded, and $3 \mathrm{~mL}$ of $2 \mathrm{M}$ $\mathrm{H}_{2} \mathrm{SO}_{4}$ was added to the sediment and then dissolved. The $\mathrm{H}_{2} \mathrm{O}_{2}$ content was expressed as millimoles per gram of FW.

\subsection{Antioxidant Enzyme Assays}

Enzyme extracts were prepared by homogenizing $1.0 \mathrm{~g}$ of scales on ice using different extraction buffers. For superoxide dismutase (SOD) and catalase (CAT), $1 \mathrm{~g}$ samples were added to $5 \mathrm{~mL}$ of extraction buffer consisting of $5 \mathrm{mM}$ dithiothreitol (DTT) and $5 \%$ PVP. For peroxidase (POD), $5 \mathrm{~mL}$ of extraction buffer consisting of $1 \mathrm{mM}$ polyethylene glycol 6000 (PEG), 4\% polyvinylpolypyrrolidone (PVPP), and 1\% Triton X-100 was used. For ascorbic acid peroxidase (APX), $5 \mathrm{~mL}$ of PBS solution ( $\mathrm{pH} 7.5$ ) consisting of $0.1 \mathrm{mM}$ EDTA, $1 \mathrm{mM}$ 
ascorbic acid, and 2\% PVP was used. For lipoxygenase (LOX), $1 \mathrm{~g}$ samples were added to $5 \mathrm{~mL}$ of extraction buffer consisting of $1 \%$ Triton- 100 and $4 \%$ PVPP. All extracts were subsequently centrifuged at $12,000 \times g$ for $30 \mathrm{~min}$ at $4{ }^{\circ} \mathrm{C}$. The supernatants were collected as the enzyme extracts for further analysis.

The method described by Beyer and Fridovich was adopted to determine the SOD activity [46]. For SOD, the reaction mixture consisted of $1.7 \mathrm{~mL}$ of $50 \mathrm{mM}$ phosphate buffer (pH 7.8), $0.3 \mathrm{~mL}$ of $130 \mathrm{mM}$ methionine (MET), $0.3 \mathrm{~mL}$ of $750 \mu \mathrm{M}$ nitro blue tetrazolium (NBT), $0.3 \mathrm{~mL}$ of $100 \mu \mathrm{M}$ EDTA- $\mathrm{Na}_{2}, 0.3 \mathrm{~mL}$ of $20 \mu \mathrm{M}$ riboflavin, and $0.1 \mathrm{~mL}$ of crude enzyme extract. The formation of blue formazan was monitored by recording the absorbance at $560 \mathrm{~nm}$. One unit of SOD activity was defined as the amount of enzyme that caused 50\% inhibition of NBT, and SOD activity was expressed as units per gram of protein.

CAT activity was determined by monitoring the disappearance of $\mathrm{H}_{2} \mathrm{O}_{2}$ by recording the decrease in absorbance at $240 \mathrm{~nm}$ [47]. The CAT activity was expressed as $\Delta \mathrm{D}_{240}$ per minute per milligram of protein.

POD activity was determined according to Venisse et al. [48]. The POD activity was assayed with a reaction mixture consisting of $3.0 \mathrm{~mL}$ of $25 \mathrm{mM}$ guaiacol solution, $200 \mu \mathrm{L}$ of $0.5 \mathrm{M} \mathrm{H}_{2} \mathrm{O}_{2}$, and $0.5 \mathrm{~mL}$ of crude enzyme extract. The POD activity was expressed as units per milligram of protein, where $\mathrm{U}=0.01 \mathrm{DOD} 470 / \mathrm{min}$.

The activity of APX was analyzed by previously described methods [49]. The assay mixture consisted of $2.6 \mathrm{~mL}$ of $50 \mathrm{mM}$ phosphate buffer ( $\mathrm{pH} 7.5$ ) comprising $0.5 \mathrm{mM}$ ascorbic acid and $0.1 \mathrm{mM}$ EDTA, $0.3 \mathrm{~mL}$ of $2 \mathrm{mM} \mathrm{H}_{2} \mathrm{O}_{2}$, and $0.1 \mathrm{~mL}$ of crude enzyme extract. The APX activity was expressed as $\triangle \mathrm{OD}_{290}$ per minute per milligram of protein.

The LOX activity was measured by the modified method of Surrey [50]. The assay mixture (total volume of $3 \mathrm{~mL}$ ) consisted of $2.75 \mathrm{~mL}$ of $100 \mathrm{mM}$ borate buffer (pH 5.5), $50 \mu \mathrm{L}$ of $100 \mathrm{mM}$ sodium soyate, and $200 \mu \mathrm{L}$ of enzyme extract. The reaction was carried out at $30{ }^{\circ} \mathrm{C}$ for $10 \mathrm{~min}$, and the activity of LOX was determined by measuring the absorbance at $234 \mathrm{~nm}$.

\subsection{Statistical Analysis}

The results are expressed as the means \pm SEs of three independent experiments. Statistical significance between the control and treatment samples at the same time was tested by one-way analysis of variance (ANOVA) combined with Duncan's multiple range test $(p<0.01$ or $p<0.05)$.

\section{Results}

\subsection{The $\mathrm{H}_{2} \mathrm{~S}$ Donor NaHS Prolongs Postharvest Shelf-Life}

The postharvest shelf-life of Lanzhou lily scales in response to different concentrations of NaHS was measured (Figure 1). Although the overall trends of the FW change the percentage of the scales declined during storage, there was no significant difference among any of the treatments (Figure 1A). The scales were categorized into three different grades $(1,2$, and 3$)$ according to the percentage of browning surface area, as shown in Figure 1B. On the basis of scale grades and a limit of the FW change percentage equal to $30 \%$, the postharvest shelf-life was evaluated (as shown in Figure 1C). Figure 1C shows that NaHS exhibited a dose-dependent effect on postharvest shelf-life. Compared with the control treatment, 0.2 and $0.4 \mathrm{mM} \mathrm{NaHS}$ cause no significant difference in postharvest shelf-life. However, $0.6 \mathrm{mM}, 0.8 \mathrm{mM}$, and $1 \mathrm{mM}$ NaHS significantly increased shelf-life. Among them, the maximum postharvest shelf-life was obtained in response to $0.8 \mathrm{mM} \mathrm{NaHS}$ (Figure 1A,B). In addition, Figure 1D shows the phenotype of scales after storage for 12 days. Combined with the previous results shown in Figure 1, these results suggest that NaHS was able to prolong the postharvest shelf life of the scales of Lanzhou lily.

\subsection{NaHS Treatment Alters Endogenous $\mathrm{H}_{2} \mathrm{~S}$ Contents}

As shown in Figure 2, the endogenous $\mathrm{H}_{2} \mathrm{~S}$ content of scales under both the control and $\mathrm{NaHS}$ treatments tended to increase throughout the 9-day storage period, albeit slowly. 
However, the endogenous $\mathrm{H}_{2} \mathrm{~S}$ in the NaHS-treated scales was extremely significantly higher than that in the control scales during the first 9 days of storage (Figure 2). These results suggest that $\mathrm{H}_{2} \mathrm{~S}$ fumigation elicited endogenous $\mathrm{H}_{2} \mathrm{~S}$ production, which may be involved in the senescence of Lanzhou lily scales.
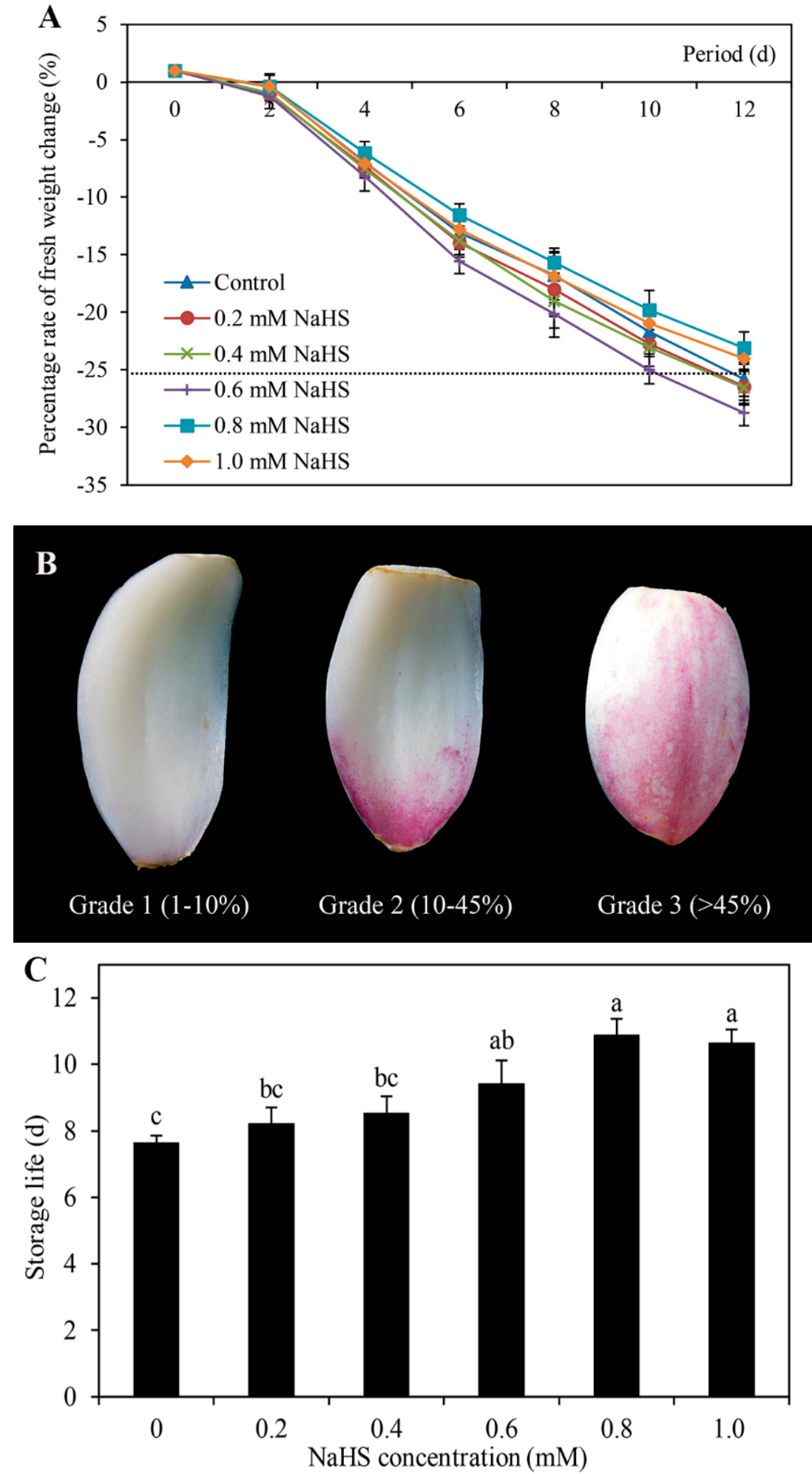

Figure 1. Cont. 


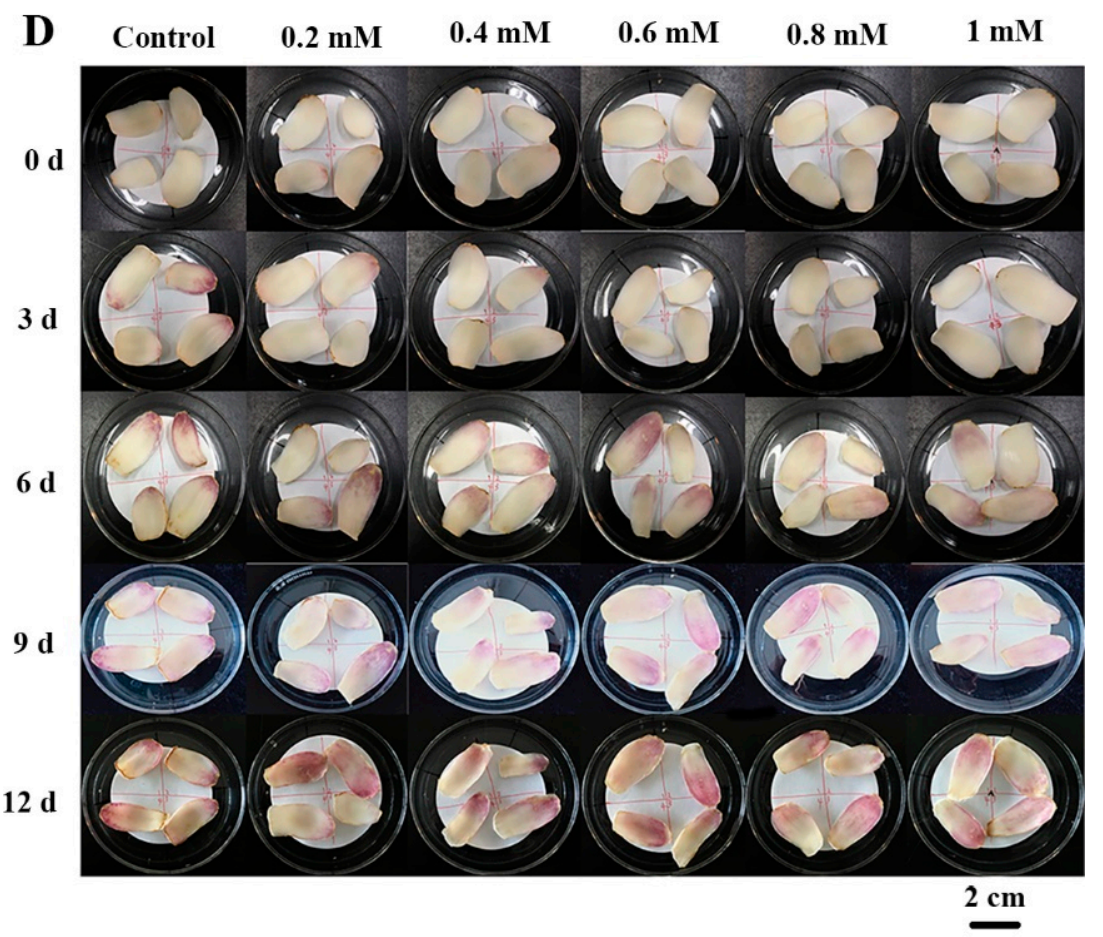

Figure 1. Changes in the fresh weight rate (A), scales grades (B), storage life $(\mathbf{C})$ and phenotype (D) of Lanzhou lily scales fumigated with different concentrations of NaHS at room temperature. The concentrations of NaHS were $0,0.2,0.4,0.6,0.8$, and $1 \mathrm{mM}$. The error bars denote the standard errors $(n=3)$. The different letters above the bars in Figure $1 \mathrm{C}$ indicate significant differences $(p<0.05)$ according to one-way ANOVA and Duncan's multiple range test. d: days.

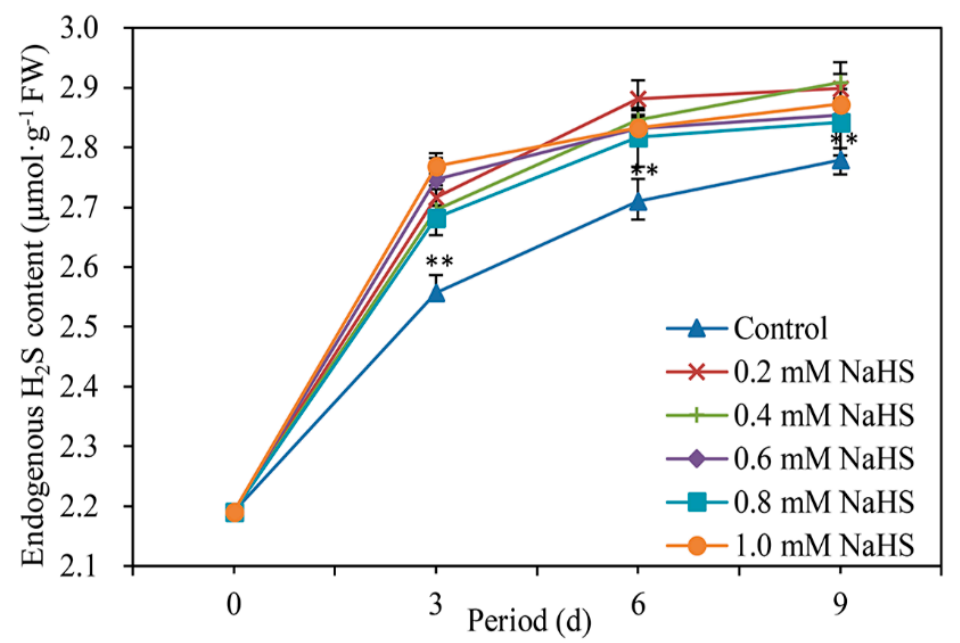

Figure 2. Effects of different concentrations of $\mathrm{NaHS}$ treatments on the endogenous $\mathrm{H}_{2} \mathrm{~S}$ content in Lanzhou lily scales during storage at room temperature for 9 days. The concentrations of NaHS were $0,0.2,0.4,0.6,0.8$, and $1 \mathrm{mM}$. The error bars denote the standard errors $(n=3)$. The asterisks denote Duncan's multiple range test for significance: ${ }^{* *} p<0.01$. d: days.

\subsection{NaHS Alleviates Decreases in Nutritional Quality of Scales}

Figure $3 \mathrm{~A}$ shows that the soluble sugar content in scales treated with or without $\mathrm{NaHS}$ solution increased slightly and peaked on day 3 , followed by a gradual decrease until the end of storage. Nevertheless, compared with the control treatment, the NaHS treatment sustained a slightly higher soluble sugar content during storage (Figure 3A).

Similar to the soluble sugar content, the soluble protein content tended to increase first but then decreased throughout the storage period. However, soluble protein degradation 
was extremely significantly inhibited by NaHS on days 6 and 9 and was significantly inhibited on day 12 (Figure 3B).

Figure $3 \mathrm{C}$ illustrates a decreasing trend of ascorbic acid content in scales fumigated with or without $\mathrm{H}_{2} \mathrm{~S}$ during storage, while NaHS significantly alleviated this decrease and resulted in the maintenance of a higher level of ascorbic acid compared with that of the control (Figure 3C).

The total phenol content in the scales tended to increase during storage (Figure 3D). Lower total phenol levels were detected in NaHS-treated scales than in the control scales, which was similar to the findings concerning flavonoids. Compared with that in the untreated control scales, the flavonoid content in the NaHS-treated scales decreased by approximately $29.56 \%$ and $19.21 \%$ on days 6 and 9 of storage, respectively (Figure 3E), suggesting that $\mathrm{H}_{2} \mathrm{~S}$ can alleviate tendency for flavonoids to decrease during storage.

\subsection{NaHS Suppresses the MDA Content, Relative Conductivity, and LOX Activity}

The level of MDA in scales with or without NaHS treatment was compared, the results of which are shown in Figure 4A. The MDA content in the control sample increased continuously within the first 9 days of storage, followed by a decrease until the end of storage. NaHS treatment significantly inhibited the increase in MDA content, but the inhibitory effect of NaHS was not significant after 9 days of storage (Figure 4A).
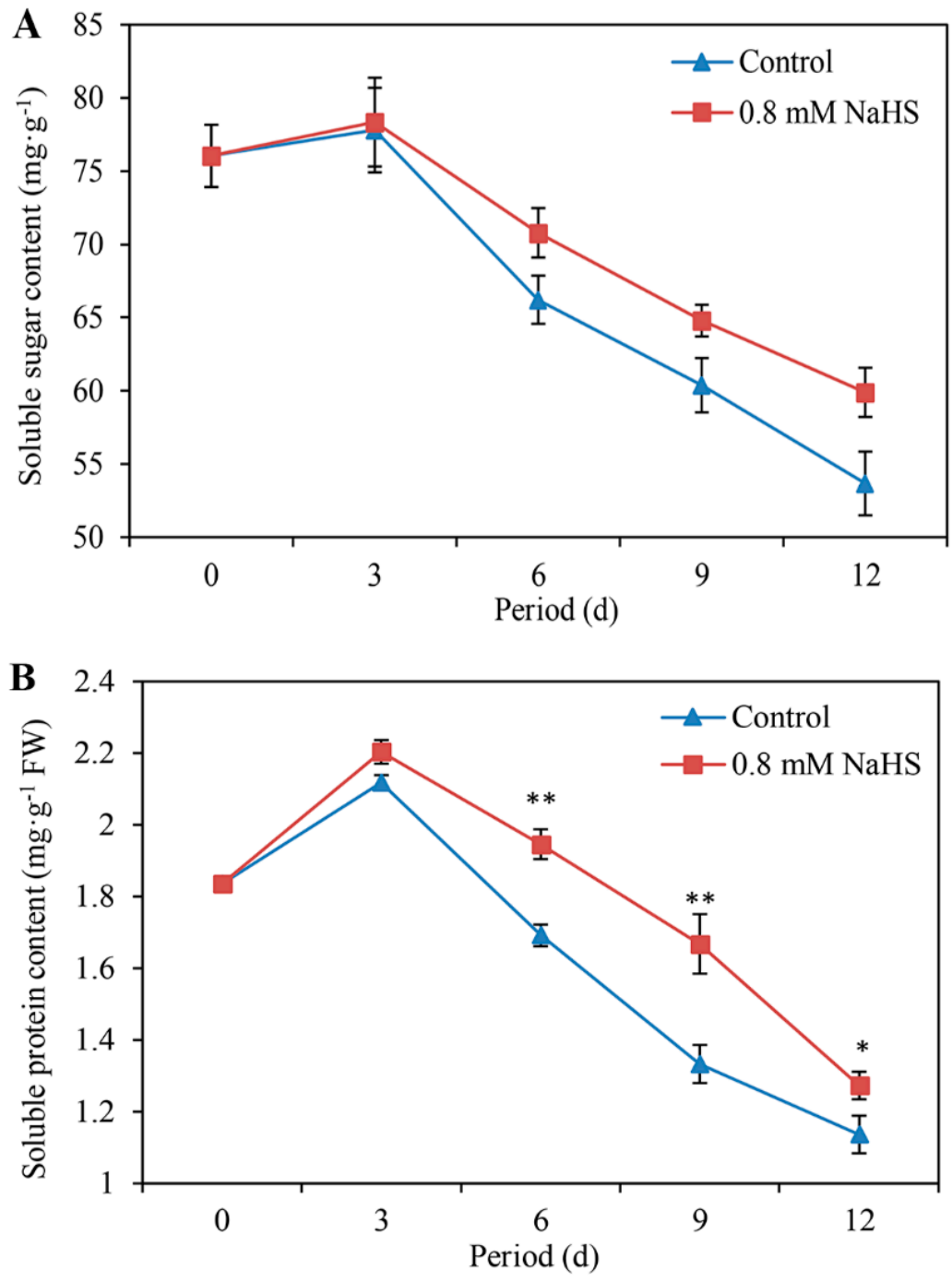

Figure 3. Cont. 

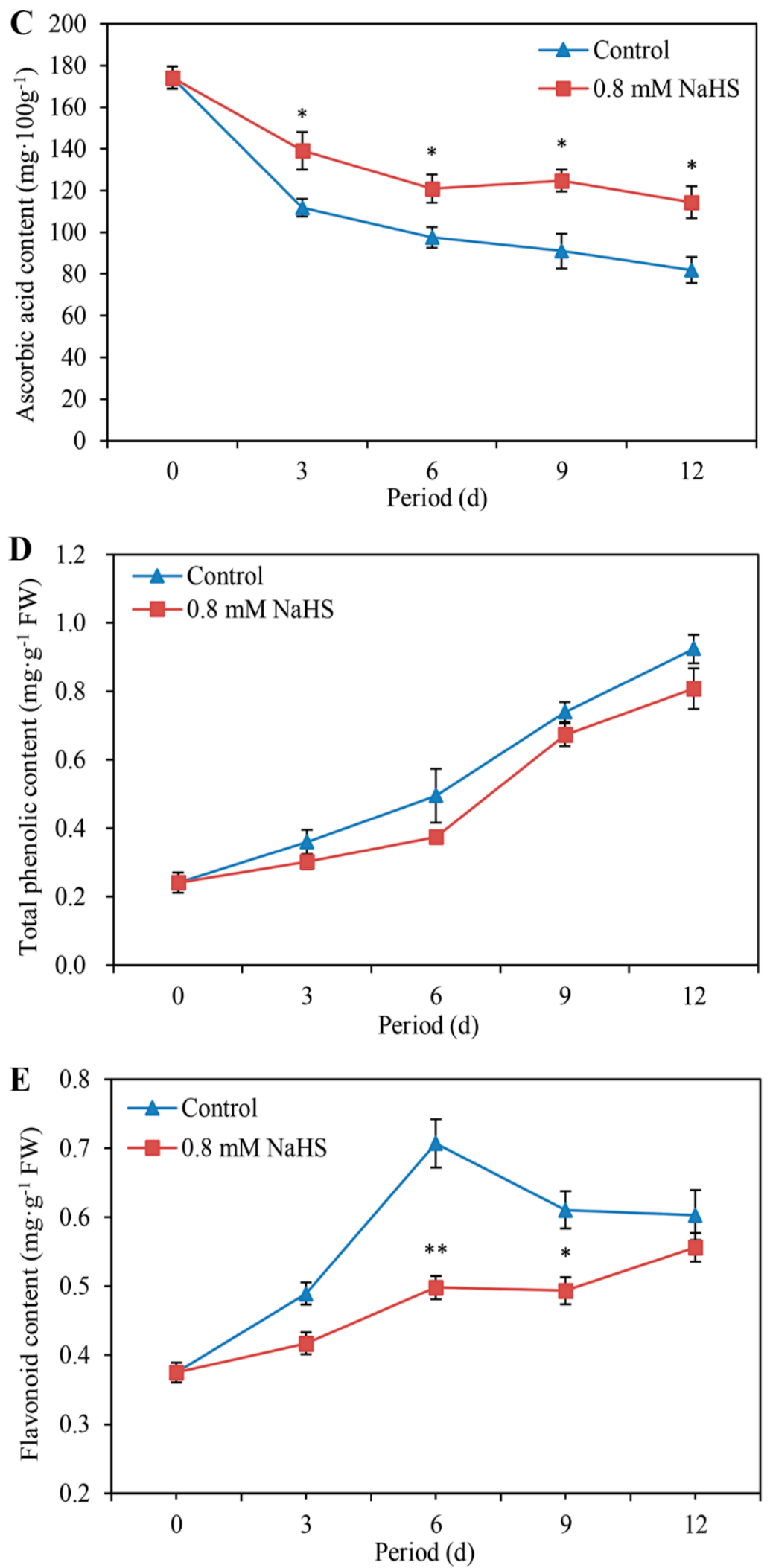

Figure 3. Changes in the contents of soluble sugars (A), soluble protein (B), ascorbic acid (C), total phenols (D), and flavonoids (E) of Lanzhou lily scales fumigated with or without $0.8 \mathrm{mM}$ NaHS during storage at room temperature for 12 days. The error bars denote the standard errors $(n=3)$. The asterisks denote Duncan's multiple range test for significance: ${ }^{*} p<0.05 ;{ }^{* *} p<0.01$. d: days. 

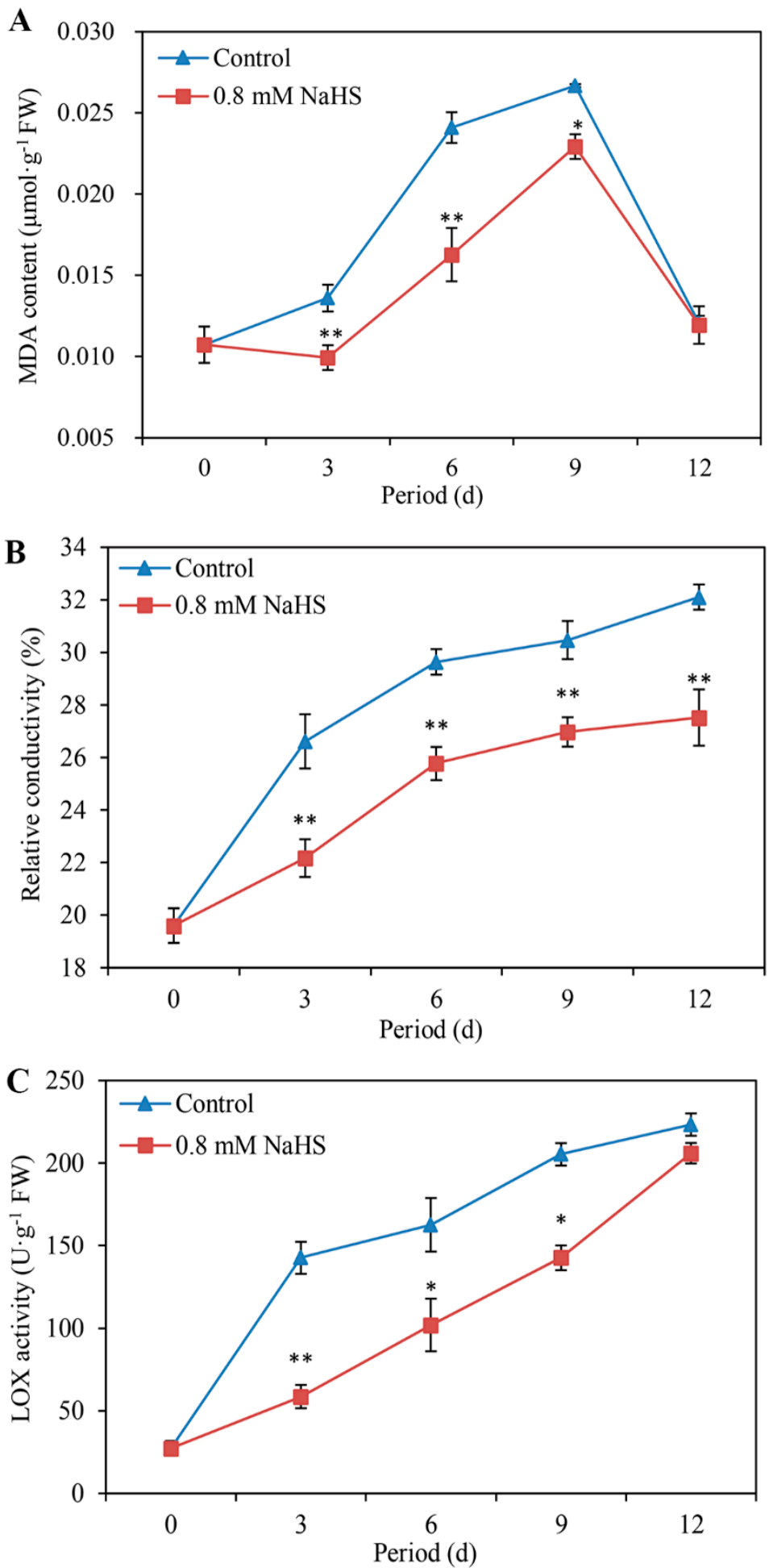

Figure 4. Effects of $0.8 \mathrm{mM} \mathrm{NaHS}$ on MDA content (A), relative conductivity (B), and LOX activity (C) of Lanzhou lily scales. The error bars denote the standard errors $(n=3)$. The asterisks denote Duncan's multiple range test for significance: ${ }^{*} p<0.05 ;{ }^{* *} p<0.01$. d: days.

The relative conductivity of scales tended to increase in all the samples during the storage period. Compared with that in the control scales, the relative conductivity in the $\mathrm{H}_{2} \mathrm{~S}$-treated scales extremely significantly decreased during storage, decreasing by approximately $20.05 \%, 15.01 \%, 12.97 \%$, and $16.66 \%$ on days $3,6,9$, and 12 , respectively (Figure 4B). 
Figure $4 \mathrm{C}$ shows that the LOX activity of the scales under both treatments increased gradually during storage. However, such increases were suppressed by $\mathrm{H}_{2} \mathrm{~S}$ fumigation (Figure 4C).

\subsection{NaHS Decreases the $\mathrm{O}_{2}{ }^{-}$Production Rate and $\mathrm{H}_{2} \mathrm{O}_{2}$ Content}

The $\mathrm{O}_{2}{ }^{-}$production rate and $\mathrm{H}_{2} \mathrm{O}_{2}$ content were almost differentially blocked in NaHS-treated scales during storage (Figure 5A,B). Compared with that in the control scales, the $\mathrm{O}_{2}{ }^{-}$production rate in the NaHS-treated scales decreased by approximately $39.37 \%$, $34.69 \%$, and $48.84 \%$ on days 6,9 , and 12 , respectively (Figure $5 \mathrm{~A}$ ). Compared with that under the control, the $\mathrm{H}_{2} \mathrm{O}_{2}$ content under the NaHS treatment was reduced by $12.04 \%$, $12.04 \%$, and $25.28 \%$ on days 6,9 , and 12 , respectively (Figure $5 \mathrm{~B}$ ). There was a significant difference on days 6 and 9 and an extremely significant difference on day 12 .
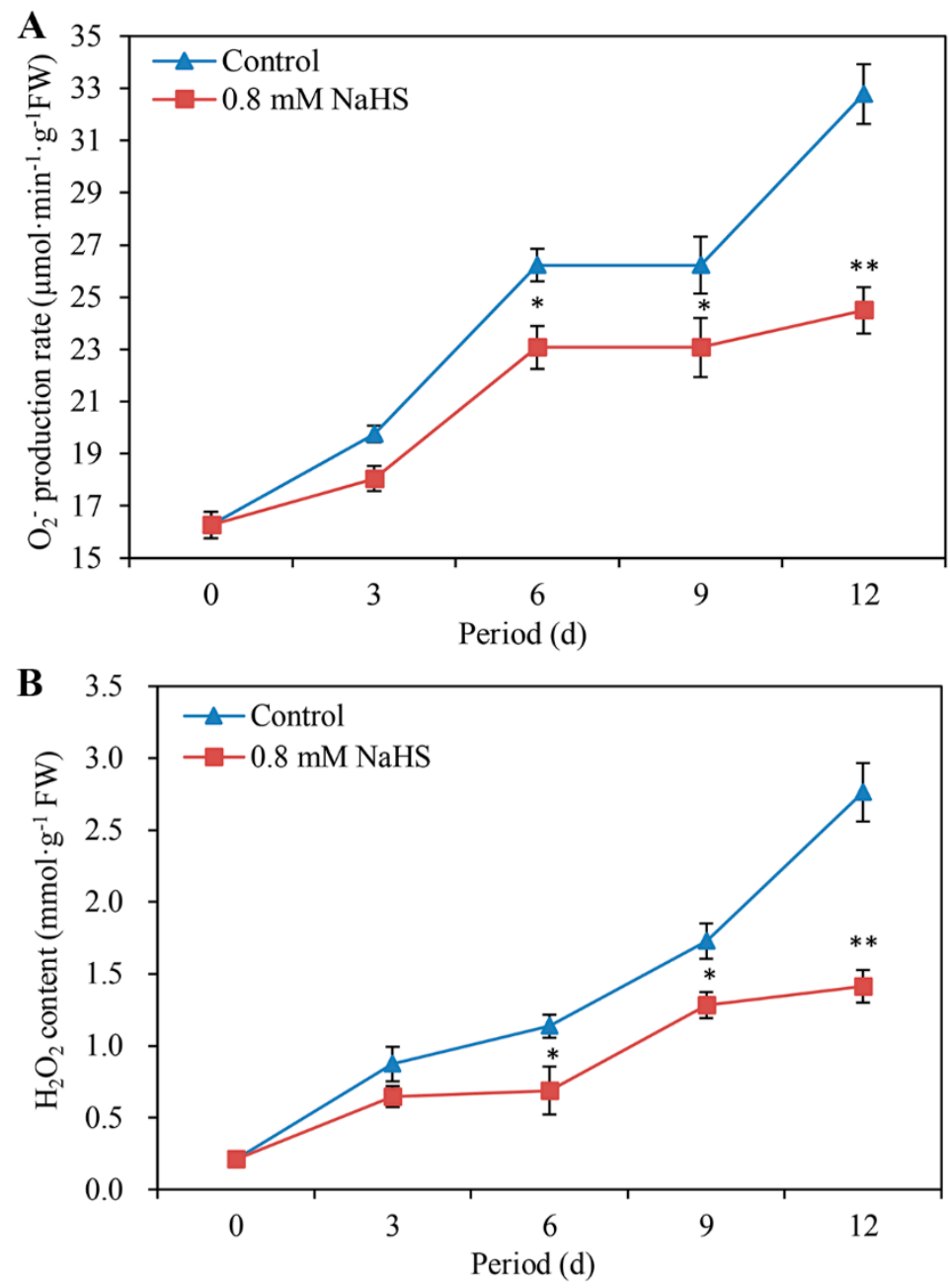

Figure 5. Changes in $\mathrm{O}_{2}{ }^{-}$production rate (A) and $\mathrm{H}_{2} \mathrm{O}_{2}$ content (B) in Lanzhou lily scales with or without $0.8 \mathrm{mM}$ NaHS treatment during storage at room temperature for 12 days. The error bars denote the standard errors $(n=3)$. The asterisks denote Duncan's multiple range test for significance: ${ }^{*} p<0.05 ;{ }^{* *} p<0.01$. d: days.

\subsection{Effects of NaHS on SOD, POD, CAT, and APX Activities}

Figure $6 \mathrm{~A}$ shows that the SOD activity decreased gradually during different storage periods. The time course analysis showed that the SOD activity in NaHS-treated scales was initially approximately $0.71 \mathrm{U} \cdot \mathrm{g}^{-1}$ but decreased by $23.94 \%$ on day 12 . The SOD activity under the NaHS treatment was significantly higher than that under the control treatment on day 3 (Figure 6A). 

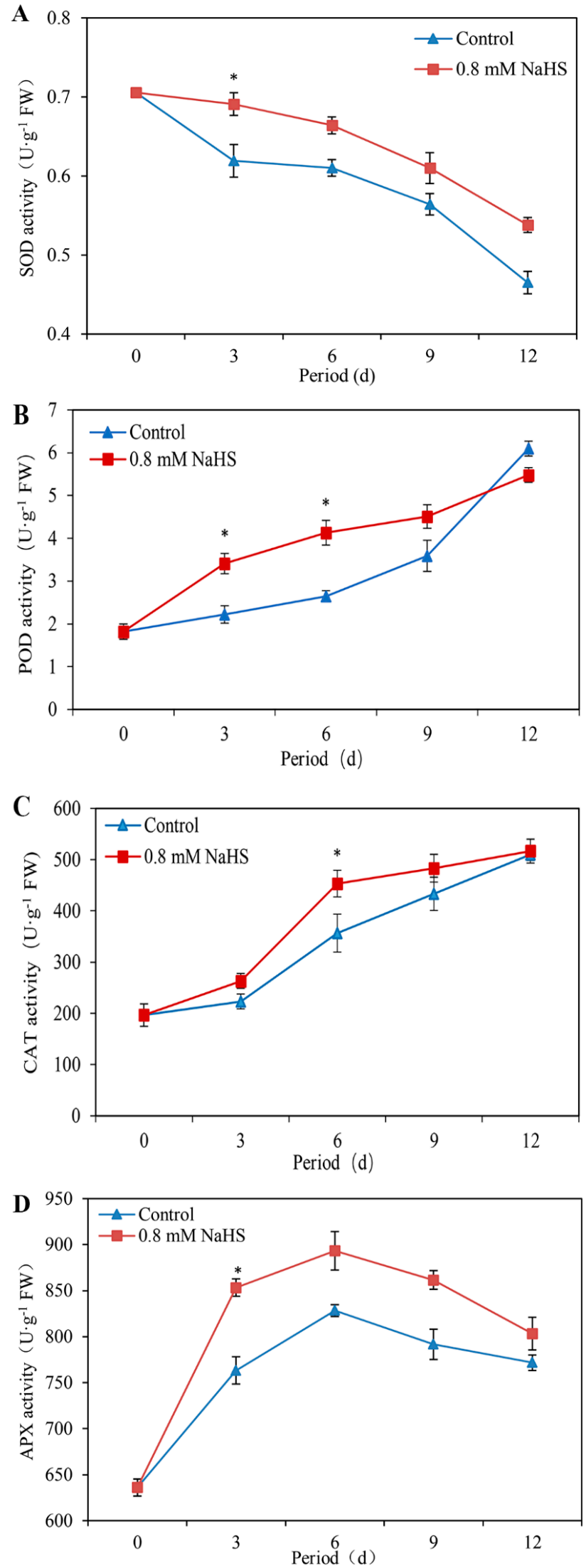

Figure 6. Changes in enzyme activities in Lanzhou lily scales with or without $0.8 \mathrm{mM} \mathrm{NaHS}$ treatment during storage at room temperature for 12 days. (A) SOD, superoxide dismutase; (B) POD, peroxidase; (C) CAT, catalase; (D) APX, ascorbic acid peroxidase. The error bars denote the standard errors $(n=3)$. The asterisks denote Duncan's multiple range test for significance: ${ }^{*} p<0.05$. d: days. 
Figure $6 \mathrm{~B}$ illustrates that during storage, the POD activity of the scales increased gradually. In comparison with that in the control scales, the level of POD activity in the NaHS-treated scales increased by approximately 1.54-fold and 1.56-fold on days 3 and 6 of storage, respectively. Moreover, the POD activity rose sharply without NaHS treatment after 9 days of storage (Figure 6B).

Similarly, the CAT activity under both treatments constantly increased during storage. Compared with that in the control samples, the CAT activity in NaHS-treated samples increased by approximately 1.27-fold and was significantly different on day 6 (Figure 6C).

As shown in Figure 6D, the APX activity in scales with or without NaHS treatment first increased but then decreased throughout the storage period. Compared with that in the control scales, the APX activity in the NaHS-treated scales markedly differed on day 3. In addition, the APX activity under all the treatments decreased gradually after 6 days of storage (Figure 6D).

\section{Discussion}

As a gaseous signal transmitter, $\mathrm{H}_{2} \mathrm{~S}$ has been known to participate in plant growth and development $[15,27]$ and to the response to stresses $[19,27] . \mathrm{H}_{2} \mathrm{~S}$ has attracted much attention due to its strong antioxidative function and scavenging activity [11,51]. Recently, $\mathrm{H}_{2} \mathrm{~S}$ was also shown to be strongly correlated with plant postharvest senescence. Li et al. [52] reported that $\mathrm{H}_{2} \mathrm{~S}$ alleviated the yellowing of broccoli florets, suggesting that $\mathrm{H}_{2} \mathrm{~S}$ prolonged the shelf-life of postharvest broccoli. Al Ubeed et al. [36] showed that $\mathrm{H}_{2} \mathrm{~S}$ inhibited senescence of harvested pak-choi during storage. $\mathrm{H}_{2} \mathrm{~S}$ played a vital role in delaying leaf yellowing and in water spinach [32] and effectively alleviated postharvest and rotting of grape [33]. $\mathrm{H}_{2} \mathrm{~S}$ also prolonged kiwifruit storage time [28]. The results presented here demonstrate that exogenous $\mathrm{H}_{2} \mathrm{~S}$ fumigation prolonged the postharvest shelf-life of Lanzhou lily scales (Figure 1). It appears that $\mathrm{H}_{2} \mathrm{~S}$ is able to significantly extend the shelf-life of postharvest Lanzhou lily scales.

$\mathrm{NaHS}$ fumigation-induced increases in endogenous $\mathrm{H}_{2} \mathrm{~S}$ production in Lanzhou lily scales during storage were also observed in this study (Figure 2). This revealed a remarkably close relationship between endogenous $\mathrm{H}_{2} \mathrm{~S}$ and postharvest senescence. Li et al. [52] showed that the endogenous $\mathrm{H}_{2} \mathrm{~S}$ in $\mathrm{H}_{2} \mathrm{~S}$-treated broccoli florets was significantly higher than that in the control samples. Tang et al. [30] also reported that the endogenous $\mathrm{H}_{2} \mathrm{~S}$ content in $\mathrm{H}_{2} \mathrm{~S}$-treated mulberry fruits was significantly higher than that in the control fruits on day 2. The level of endogenous $\mathrm{H}_{2} \mathrm{~S}$ in maize seedlings treated with two $\mathrm{H}_{2} \mathrm{~S}$ donors, NaHS and GYY4137, was also shown to increase [53]. Aghdam et al. [47] also reported that endogenous $\mathrm{H}_{2} \mathrm{~S}$ in hawthorn fruits fumigated with $\mathrm{H}_{2} \mathrm{~S}$ accumulated during cold storage. NaHS fumigation induced endogenous $\mathrm{H}_{2} \mathrm{~S}$ synthesis during storage of water spinach [32]. Hu et al. [35] reported that NaHS fumigation played a role in the preservation of mulberries by enhancing endogenous $\mathrm{H}_{2} \mathrm{~S}$ content. Thus, endogenous $\mathrm{H}_{2} \mathrm{~S}$ might be involved in the postharvest storage process of scales.

It has been shown that Lanzhou lily scales are rich in nutrient elements and are considered edible vegetables due to their high nutritional value [53]. Postharvest losses of nutritional quality of scales due to physiological changes may decrease the nutritional benefits from the consumption of scales. Thus, whether $\mathrm{H}_{2} \mathrm{~S}$ can maintain the nutritional quality of Lanzhou lily scales was investigated. In the present study, the $\mathrm{H}_{2} \mathrm{~S}$ donor NaHS was able to alleviate the decrease in soluble sugar, soluble protein, and ascorbic acid contents and to increase the total phenolic and flavonoids in scales during storage at room temperature (Figure 3). Similarly, a previous study provided evidence of the involvement of $\mathrm{H}_{2} \mathrm{~S}$ in maintaining a higher content of soluble proteins in kiwifruit [54]. $\mathrm{H}_{2} \mathrm{~S}$ fumigation slowed down the decrease in soluble protein during the storage of mulberries [35]. Ni et al. [33] reported that grape berries treated with NaHS presented significantly higher soluble protein, ascorbic acid, and total phenolic and flavonoid levels. However, the results presented by Ge et al. [55] showed that banana fruits treated with $\mathrm{H}_{2} \mathrm{~S}$ had lower levels of soluble proteins and higher levels of total phenolics with increasing storage time. One 
possible explanation for this discrepancy could be that $\mathrm{H}_{2} \mathrm{~S}$ signal transduction pathway changes occur during storage. Therefore, as a preservative, $\mathrm{H}_{2} \mathrm{~S}$ might reduce nutrient loss during horticultural product storage.

Lipid peroxidation mediated mainly by LOX is involved in plant ripening and senescence [56]. MDA content has been shown to be an accurate indicator of lipid peroxidation for reflecting the degree of damage to plant cell membranes [57,58]. To some extent, relative conductivity is another important factor that could influence damage to the cell membrane [59]. $\mathrm{H}_{2} \mathrm{~S}$ significantly reduced the accumulation of MDA during postharvest storage of grape [33]. It was reported that $\mathrm{H}_{2} \mathrm{~S}$ protects water spinach and hawthorn against the damaging effects of lipid peroxidation and relative conductivity by inhibiting LOX activity during storage $[32,47]$. In the study, $\mathrm{H}_{2} \mathrm{~S}$ fumigation significantly suppressed LOX activity to maintain lower MDA content and relative conductivity, leading to a reduction in lipid peroxidation and membrane damage (Figure 4). This may be the reason that $\mathrm{H}_{2} \mathrm{~S}$ might prolong the storage life of Lanzhou lily scales.

Reactive oxygen species (ROS) such as $\mathrm{H}_{2} \mathrm{O}_{2}$ and $\mathrm{O}_{2}{ }^{-}$are inevitably produced as by-products of normal cell metabolism and generally are present in postharvest vegetables and fruits during storage. Excessive ROS production could result in progressive oxidative damage, thereby accelerating senescence $[60,61]$. In our study, the $\mathrm{H}_{2} \mathrm{~S}$-fumigated scales presented a lower $\mathrm{O}_{2}{ }^{-}$production rate and $\mathrm{H}_{2} \mathrm{O}_{2}$ content compared with those of the control scales (Figure 5). SOD catalyzes the reaction by which $\mathrm{O}_{2}{ }^{-}$is converted to $\mathrm{H}_{2} \mathrm{O}_{2}$, and CAT, POD, and APX are required for $\mathrm{H}_{2} \mathrm{O}_{2}$ decomposition to water [62]. Elevated activities of SOD, CAT, POD, and APX in scales exposed to NaHS were observed (Figure 6). These findings are consistent with those in the report of Zhang et al. [25], in which NaHS treatment resulted in relatively low $\mathrm{H}_{2} \mathrm{O}_{2}$ and $\mathrm{O}_{2}{ }^{-}$production rates by upregulating the activities of CAT, SOD, APX, and POD in cut flowers. Therefore, high antioxidant capacities resulting from $\mathrm{H}_{2} \mathrm{~S}$ treatment may directly prolong the storage life of Lanzhou lily scales. In higher plants, it is well known that ascorbic acid, an antioxidant, can delay or prevent the oxidation of oxidizable substrates [63]. Maintaining a high level of ascorbic acid by $\mathrm{H}_{2} \mathrm{~S}$ was also found to delay the senescence of scales (Figure 3C), which was also observed in the study of apple slices and broccoli $[27,34]$. Sun et al. [31] found that $\mathrm{H}_{2} \mathrm{~S}$ could inhibit the browning of fresh-cut lotus root slices by enhancing antioxidant enzyme activities to alleviate the oxidative damage. Therefore, $\mathrm{H}_{2} \mathrm{~S}$ suppressed $\mathrm{ROS}$ by enhancing antioxidant enzyme (SOD, CAT, APX, and POD) activities and maintaining a higher content of the non-enzymatic antioxidant ascorbic acid in Lanzhou lily scales during storage.

\section{Conclusions}

In summary, the results reveal that exogenous $\mathrm{H}_{2} \mathrm{~S}$ was able to extend the storage life of postharvest Lanzhou lily scales with an optimal concentration at $0.8 \mathrm{mM}$. NaHS fumigation elicited endogenous $\mathrm{H}_{2} \mathrm{~S}$ production, suggesting that endogenous $\mathrm{H}_{2} \mathrm{~S}$ might be involved in the postharvest senescence of Lanzhou lily scales. Compared with the control treatment, $\mathrm{H}_{2} \mathrm{~S}$ treatment resulted in higher nutritional quality during storage. Moreover, $\mathrm{H}_{2} \mathrm{~S}$ enhanced antioxidant enzyme (SOD, POD, CAT, and APX) activities and maintained higher non-enzyme antioxidant (ascorbic acid) content, leading to the inhibition of increased MDA content, relative conductivity, LOX activity, $\mathrm{O}^{2-}$ production rate, and $\mathrm{H}_{2} \mathrm{O}_{2}$ content, and consequently, alleviating the postharvest senescence of Lanzhou lily scales. Although this study will be useful for understanding the mechanisms through which $\mathrm{H}_{2} \mathrm{~S}$ affects the postharvest senescence of plant scales, the molecular mechanisms are still unknown. Thus, further studies on the mechanisms of $\mathrm{H}_{2} \mathrm{~S}$ in postharvest storage should focus on gene expression, protein modifications, and signal interactions during storage.

Author Contributions: Conceptualization, C.L. and W.L.; data curation, C.L., G.C. and D.H.; formal analysis, C.L. and G.C.; investigation, C.L. and D.H.; methodology, C.L., D.H. and N.W.; project administration, W.L.; software, C.L., G.C. and N.W.; supervision, G.C.; visualization, C.L., G.C., D.H. and N.W.; writing-original draft, C.L.; writing—review and editing, W.L. All authors have read and agreed to the published version of the manuscript. 
Funding: This work was supported by the National Natural Science Foundation of China (Nos. 32072559, 31860568, 31560563, and 31160398); the Research Fund of Higher Education of Gansu, China (No. 2018C-14 and 2019B-082); and the Natural Science Foundation of Gansu Province, China (Nos. 1606RJZA073 and 1606RJZA077 and 1606RJYA252).

Conflicts of Interest: The authors declare no conflict of interest.

\section{References}

1. Zhang, Y.B.; Wang, Y.J.; Xie, Z.K.; Yang, G.; Guo, Z.H.; Wang, L. The occurrence and distribution of viruses infecting Lanzhou lily in northwest, China. Crop Prot. 2018, 110, 73-76. [CrossRef]

2. Wang, R.; Wang, G.; Zhao, Q.; Zhu, Y.; Zhan, J.; Xie, Z.; An, L.; Wang, Y. Molecular and cytopathologic evidences for a mixed infection of multiple viruses on Lanzhou lily (Lilium davidii var. unicolor) in Northwestern China. J. Plant Dis. Protect. 2010, 117, 145-149. [CrossRef]

3. Munafo, J., Jr.; Gianfagna, T.J. Quantitative analysis of phenylpropanoid glycerol glucosides in different organs of easter lily (Lilium longiflorum Thunb.). J. Agric. Food Chem. 2015, 63, 4836-4842. [CrossRef] [PubMed]

4. Jin, L.; Zhang, Y.; Yan, L.; Guo, Y.; Niu, L. Phenolic compounds and antioxidant activity of bulb extracts of six Lilium species native to China. Molecules 2012, 17, 9361-9378. [CrossRef] [PubMed]

5. You, X.J.; Xie, C.Y.; Liu, K.L.; Gu, Z.X. Isolation of non-starch polysaccharides from bulb of tiger lily (Lilium lancifolium Thunb.) with fermentation of Saccharomyces cerevisiae. Carbohyd. Polym. 2010, 81, 35-40. [CrossRef]

6. Zhang, D.N.; Guo, X.Y.; Chen, Z.G. A novel and efficient method for the isolation and purification of polysaccharides from lily bulbs by Saccharomyces cerevisiae fermentation. Process Biochem. 2014, 49, 2299-2304. [CrossRef]

7. Tian, X.H.; Xie, J.M.; Yu, J.H. Physiological and transcriptomic responses of Lanzhou Lily (Lilium davidii, var. unicolor) to cold stress. PLoS ONE 2020, 15, e0227921. [CrossRef]

8. Fu, L.H.; Hu, K.D.; Hu, L.Y.; Li, Y.H.; Hu, L.B.; Yan, H.; Liu, Y.S.; Zhang, H. An antifungal role of hydrogen sulfide on the postharvest pathogens Aspergillus niger and Penicillium italicum. PLoS ONE 2014, 9, e104206. [CrossRef] [PubMed]

9. García-Mata, C.; Lamattina, L. Hydrogen sulphide, a novel gasotransmitter involved in guard cell signalling. New Phytol. 2010, 188, 977-984. [CrossRef]

10. Li, D.; Limwachiranon, J.; Li, L.; Du, R.X.; Luo, Z.S. Involvement of energy metabolism to chilling tolerance induced by hydrogen sulfide in cold-stored banana fruit. Food Chem. 2016, 208, 272-278. [CrossRef]

11. Hancock, J.T.; Whiteman, M. Hydrogen sulfide and cell signaling: Team player or referee? Plant Physiol. Biochem. 2014, 78, 37-42. [CrossRef]

12. Wang, R. Physiological implications of hydrogen sulfide: A whiff exploration that blossomed. Physiol. Rev. 2012, 92, 791-896. [CrossRef] [PubMed]

13. Mathai, J.C.; Missner, A.; Kugler, P.; Saparov, S.M.; Zeidel, M.L.; Lee, J.K.; Pohl, P. No facilitator required for membrane transport of hydrogen sulfide. Proc. Natl. Acad. Sci. USA 2009, 106, 16633-16638. [CrossRef] [PubMed]

14. Li, Z.G.; Gong, M.; Liu, P. Hydrogen sulfide is a mediator in $\mathrm{H}_{2} \mathrm{O}_{2}$-induced seed germination in Jatropha Curcas. Acta Physiol. Plant. 2012, 34, 2207-2213. [CrossRef]

15. Dooley, F.D.; Nair, S.P.; Ward, P.D. Increased growth and germination success in plants following hydrogen sulfide administration. PLoS ONE 2013, 8, e62048. [CrossRef] [PubMed]

16. Jin, Z.; Pei, Y. Hydrogen sulfide: The shutter button of stomata in plants. Sci. China Life Sci. 2016, 59, 1187-1188. [CrossRef] [PubMed]

17. Kou, N.H.; Xiang, Z.X.; Cui, W.T.; Li, L.N.; Shen, W.B. Hydrogen sulfide acts downstream of methane to induce cucumber adventitious root development. J. Plant. Physiol. 2018, 228, 113-120. [CrossRef]

18. Chen, J.; Shang, Y.T.; Wang, W.H.; Chen, X.Y.; He, E.M.; Zheng, H.L.; Shangguan, Z.P. Hydrogen sulfide-mediated polyamines and sugar changes are involved in hydrogen sulfide-induced drought tolerance in Spinacia oleracea seedlings. Front. Plant. Sci. 2016, 7, 1173. [CrossRef]

19. Jin, Z.P.; Wang, Z.Q.; Ma, Q.X.; Sun, L.M.; Zhang, L.P.; Liu, Z.Q.; Liu, D.M.; Hao, X.F.; Pei, Y.X. Hydrogen sulfide mediates ion fluxes inducing stomatal closure in response to drought stress in Arabidopsis thaliana. Plant Soil 2017, 419, 141-152. [CrossRef]

20. Khan, M.N.; Mobin, M.; Abbas, Z.K.; Siddiqui, M.H. Nitric oxide-induced synthesis of hydrogen sulfide alleviates osmotic stress in wheat seedlings through sustaining antioxidant enzymes, osmolyte accumulation and cysteine homeostasis. Nitric Oxide 2017, 68, 91-102. [CrossRef]

21. Lai, D.W.; Mao, Y.; Zhou, H.; Li, F.; Wu, M.Z.; Zhang, J.; He, Z.Y.; Cui, W.T.; Xie, Y.J. Endogenous hydrogen sulfide enhances salt tolerance by coupling the reestablishment of redox homeostasis and preventing salt-induced $\mathrm{K}^{+}$loss in seedlings of Medicago sativa. Plant. Sci. 2014, 225, 117-129. [CrossRef] [PubMed]

22. Fu, P.; Wang, W.; Hou, L.; Liu, X. Hydrogen sulfide is involved in the chilling stress response in Vitis vinifera L. Acta Soc. Bot. Pol. 2013, 82, 295. [CrossRef]

23. Ali, B.; Qian, P.; Sun, R.; Farooq, M.A.; Gill, R.A.; Wang, J.; Azam, M.; Zhou, W. Hydrogen sulfide alleviates the aluminum-induced changes in Brassica napus as revealed by physiochemical and ultrastructural study of plant. Environ. Sci. Pollut. Res. 2015, 22, 3068-3081. [CrossRef] 
24. Fang, H.H.; Liu, Z.Q.; Long, Y.P.; Liang, Y.; Jin, Z.P.; Zhang, L.P.; Liu, D.M.; Li, H.; Zhai, J.X.; Pei, Y.X. The Ca ${ }^{2+} /$ CaM $_{2}$ binding transcription factor TGA3 elevates LCD expressionand $\mathrm{H}_{2} \mathrm{~S}$ production to bolster $\mathrm{Cr}^{6+}$ tolerance in Arabidopsis. Plant. J. 2017, 91, 1038-1050. [CrossRef] [PubMed]

25. Zhang, H.; Hu, S.L.; Zhang, Z.J.; Hu, L.Y.; Jiang, C.X.; Wei, Z.J.; Liu, J.; Wang, H.L.; Jiang, S.T. Hydrogen sulfide acts as a regulator of flower senescence in plants. Postharvest Biol. Technol. 2011, 60, 251-257. [CrossRef]

26. Hu, L.Y.; Hu, S.L.; Wu, J.; Li, Y.H.; Zheng, J.L.; Wei, Z.J.; Liu, J.; Wang, H.L.; Liu, Y.S.; Zhang, H. Hydrogen sulfide prolongs postharvest shelf life of strawberry and plays an antioxidative role in fruits. J. Agric. Food Chem. 2012, 60, 8684-8693. [CrossRef]

27. Li, S.P.; Hu, K.D.; Hu, L.Y.; Li, Y.H.; Jiang, A.M.; Xiao, F.; Han, Y.; Liu, Y.S.; Zhang, H. Hydrogen sulfide alleviates postharvest senescence of broccoli by modulating antioxidant defense and senescence-related gene expression. J. Agric. Food Chem. 2014, 62, 1119-1129. [CrossRef] [PubMed]

28. Zhu, L.; Wang, W.; Shi, J.; Zhang, W.; Shen, Y.; Du, H.; Wu, S. Hydrogen sulfide extends the postharvest life and enhances antioxidant activity of kiwifruit during storage. J. Sci. Food Agric. 2014, 94, 2699-2704. [CrossRef] [PubMed]

29. Hu, K.D.; Wang, Q.; Hu, L.Y.; Gao, S.P.; Wu, J.; Li, Y.H.; Zheng, J.L.; Han, Y.; Liu, Y.S.; Zhang, H. Hydrogen sulfide prolongs postharvest storage of fresh-cut pears (Pyrus pyrifolia) by alleviation of oxidative damage and inhibition of fungal growth. PLoS ONE 2014, 9, e85524. [CrossRef] [PubMed]

30. Tang, J.; Hu, K.D.; Hu, L.Y.; Li, Y.H.; Liu, Y.S.; Zhang, H. Hydrogen sulfide acts as a fungicide to alleviate senescence and decay in fresh-cut sweet potato. HortScience 2014, 49, 938-943. [CrossRef]

31. Sun, Y.; Zhang, W.; Zeng, T.; Nie, Q.; Zhang, F.; Zhu, L. Hydrogen sulfide inhibits enzymatic browning of fresh-cut lotus root slices by regulating phenolic metabolism. Food Chem. 2015, 177, 376-381. [CrossRef]

32. Hu, H.; Liu, D.; Li, P.; Shen, W. Hydrogen sulfide delays leaf yellowing of stored water spinach (Ipomoea aquatica) during dark-induced senescence by delaying chlorophyll breakdown, maintaining energy status and increasing antioxidative capacity. Postharvest Biol. Technol. 2015, 108, 8-20. [CrossRef]

33. Ni, Z.J.; Hu, K.D.; Song, C.B.; Ma, R.H.; Li, Z.R.; Zheng, J.L.; Fu, L.H.; Wei, Z.J.; Zhang, H. Hydrogen sulfide alleviates postharvest senescence of grape by modulating the antioxidant defenses. Oxid. Med. Cell Longev. 2016, 4715651. [CrossRef] [PubMed]

34. Zheng, J.L.; Hu, L.Y.; Hu, K.D.; Wu, J.; Yang, F.; Zhang, H. Hydrogen Sulfide alleviates senescence of fresh-cut apple by regulating antioxidant defense system and senescence-related gene expression. HortScience 2016, 51, 152-158. [CrossRef]

35. Hu, H.; Shen, W.; Li, P. Effects of hydrogen sulphide on quality and antioxidant capacity of mulberry fruit. Int. J. Food Sci. Technol. 2014, 49, 399-409. [CrossRef]

36. Al Ubeed, H.M.S.; Wills, R.B.H.; Bowyer, M.C.; Golding, J.B. Inhibition of postharvest senescence of green leafy vegetables by exogenous D-cysteine and L-cysteine as precursors of hydrogen sulphide. J. Hortic. Sci. Biotechnol. 2019, 94, 1-7. [CrossRef]

37. Zhu, C.Q.; Zhang, J.H.; Sun, L.M.; Zhu, L.F.; Abliz, B.; Hu, W.J.; Zhong, C.; Bai, Z.G.; Sajid, H.; Cao, X.C.; et al. Hydrogen sulfide alleviates aluminum toxicity via decreasing apoplast and symplast Al contents in rice. Front. Plant. Sci. 2018, 9, 294. [CrossRef] [PubMed]

38. Yemm, E.W.; Willis, A.J. The estimation of carbohydrates in plant extracts by anthrone. Biochem. J. 1954, 57, 508-514. [CrossRef] [PubMed]

39. Bradford, M.M. A rapid and sensitive method for the quantitation of microgram quantities of protein utilizing the principle of protein-dye binding. Anal. Biochem. 1976, 72, 248-254. [CrossRef]

40. Contreras-Calderón, J.; Calderón-Jaimes, L.; Guerra-Hernández, E.; García-Villanova, B. Antioxidant capacity, phenolic content and vitamin C in pulp, peel and seed from 24 exotic fruits from Colombia. Food Res. Int. 2011, 44, 2047-2053. [CrossRef]

41. Liu, C.; Zheng, H.; Sheng, K.; Liu, W.; Zheng, L. Effects of melatonin treatment on the postharvest quality of strawberry fruit. Postharvest Biol. Tec. 2018, 139, 47-55. [CrossRef]

42. Jia, Z.S.; Tang, M.C.; Wu, J.M. The determination of flavonoid contents in mulberry and their scavenging effects on superoxide radicals. Food Chem. 1999, 64, 555-559.

43. Ma, Q.; Zhang, T.; Zhang, P.; Wang, Z.Y. Melatonin attenuates postharvest physiological deterioration of cassava storage roots. J. Pineal. Res. 2016, 60, 424-434. [CrossRef] [PubMed]

44. Hu, H.; Liu, D.; Li, P. Methane delays the senescence and browning in daylily bu-ds by restablished redox homeostasis. J. Sci. Food Agr. 2018, 98, 1977-1987. [CrossRef] [PubMed]

45. Prochazkova, D.; Sairam, R.K.; Srivastava, G.C. Oxidative stress and antioxidant activity as the basis of senescence in maize leaves. Plant. Sci. 2001, 161, 765-771. [CrossRef]

46. Beyer, W.F.; Fridovich, I. Assaying for superoxide dismutase activity: Some large consequences of minor changes in conditions. Anal. Biochem. 1987, 161, 559-566. [CrossRef]

47. Aghdam, M.S.; Mahmoudi, R.; Razavi, F.; Rabiei, V.; Soleimani, A. Hydrogen sulfide treatment confers chilling tolerance in hawthorn fruit during cold storage by triggering endogenous $\mathrm{H}_{2} \mathrm{~S}$ accumulation, enhancing antioxidant enzymes activity and promoting phenols accumulation. Sci. Hortic. 2018, 238, 264-271. [CrossRef]

48. Venisse, J.S.; Gullner, G.; Brisset, M.N. Evidence for the involvement of an oxidative stress in the initiation of infection of pear by Erwinia amylovora. Plant. Physiol. 2001, 125, 2164-2172. [CrossRef]

49. Cui, W.; Qi, F.; Zhang, Y.; Cao, H.; Zhang, J.; Wang, R.; Shen, W. Methane-rich water induces cucumber adventitious rooting through heme oxygenase1/carbon monoxide and $\mathrm{Ca}^{2+}$ pathways. Plant. Cell Rep. 2015, 34, 435-445. [CrossRef]

50. Surrey, K. Spectrophotometric method for determination of lipoxidase activity. Plant. Physiol. 1964, 39, 65. [CrossRef] 
51. Yang, R.; Jia, Q.; Ma, S.F.; Wang, Y.; Mehmood, S.; Chen, Y. Exogenous $\mathrm{H}_{2} \mathrm{~S}$ mitigates myocardial fibrosis in diabetic rats through suppression of the canonical Wnt pathway. Int. J. Mol. Med. 2019, 44, 549-558. [CrossRef]

52. Li, D.; Li, L.; Ge, Z.; Limwachiranon, J.; Ban, Z.; Yang, D.; Luo, Z. Effects of hydrogen sulfide on yellowing and energy metabolism in broccoli. Postharvest Biol. Tec. 2017, 129, 136-142. [CrossRef]

53. Li, X.Y.; Wang, C.X.; Cheng, J.Y.; Zhang, J.; da Silva, J.A.T.; Liu, X.Y.; Duan, X.; Li, T.L.; Sun, H.M. Transcriptome analysis of carbohydrate metabolism during bulblet formation and development in Lilium davidii var. unicolor. BMC Plant. Biol. 2014, 14, 1-12. [CrossRef] [PubMed]

54. Gao, S.P.; Hu, K.D.; Hu, L.Y.; Li, Y.H.; Han, Y.; Wang, H.L.; Lv, K.; Liu, Y.S.; Zhang, H. Hydrogen sulfide delays postharvest senescence and plays an antioxidative role in fresh-cut kiwifruit. Hort. Sci. 2013, 48, 1385-1392. [CrossRef]

55. Ge, Y.; Hu, K.D.; Wang, S.S.; Hu, L.Y.; Chen, X.Y.; Li, Y.H.; Yang, Y.; Yang, F.; Zhang, H. Hydrogen sulfide alleviates postharvest ripening and senescence of banana by antagonizing the effect of ethylene. PLoS ONE 2017, 12, e0180113. [CrossRef] [PubMed]

56. Havir, E.A.; McHale, N.A. Biochemical and developmental characterization of multiple forms of catalase in tobacco leaves. Plant. Physiol. 1987, 84, 450-455. [CrossRef] [PubMed]

57. Khan, M.H.; Panda, S.K. Alterations in root lipid peroxidation and antioxidative responses in two rice cultivars under NaClsalinity stress. Acta Physiol. Plant. 2008, 30, 81. [CrossRef]

58. Akcay, U.C.; Ercan, O.; Kavas, M.; Yildiz, L.; Yilmaz, C.; Oktem, H.A.; Yucel, M. Drought-induced oxidative damage and antioxidant responses in peanut (Arachishypogaea L.) seedlings. Plant. Growth Regul. 2010, 61, 21-28. [CrossRef]

59. Filek, M.; Walas, S.; Mrowiec, H.; Rudolphy-Skórska, E.; Sieprawska, A.; Biesaga-Kościelniak, J. Membrane permeability and micro-and macroelement accumulation in spring wheat cultivars during the short-term effect of salinity-and PEG-induced water stress. Acta Physiol. Plant. 2012, 34, 985-995. [CrossRef]

60. Apel, K.; Hirt, H. Reactive oxygen species: Metabolism, oxidative stress, and signal transduction. Annu. Rev. Plant. Biol. 2004, 55, 373-399. [CrossRef]

61. Bhattacharjee, S. Reactive oxygen species and oxidative burst: Roles in stress, senescence and signal transducation in plants. Curr. Sci. 2005, 1113-1121.

62. Gill, S.S.; Tuteja, N. Reactive oxygen species and antioxidant machinery in abiotic stress tolerance in crop plants. Plant. Physiol Biochem. 2010, 48, 909-930. [CrossRef] [PubMed]

63. Seung, H.S.; Lee, D.D.; Reis, B.Y.; Tank, D.W. The autapse: A simple illustration of short-term analog memory storage by tuned synaptic feedback. J. Comput. Neurosci. 2000, 9, 171-185. [CrossRef] [PubMed] 